\title{
Cultural Tourism Practices in Law Tourism in Bali
}

\author{
I Wayan Wesna Astara, Ida Ayu Putu Widiati, Putu Ayu Sriasih Wesna \\ Faculty of Law \\ Universitas Warmadewa \\ Denpasar-Bali, Indonesia \\ wesna_astara@yahoo.com
}

\begin{abstract}
This article recognizes the existence of Tourism in Bali as a sustainable cultural tourism potential supported by indigenous Balinese Hindus. This study aims to contribute to the Provincial Government of Bali in regulating, protecting, maintaining the values of local indigenous cultural wisdom of Balinese people in tourism activities. Qualitative methods are focused in this article and are highly relevant especially sociolegal research. The results of research in the practice of local wisdom values in the dynamics of global tourism provide the role of indigenous villages in tourism activities. The impact of tourism activities provides welfare to the people of Bali, and for the sustainability of tourism. The role of the state at all times needs to be present in protecting the value of local wisdom of Balinese culture in public policy products.
\end{abstract}

Keywords-local wisdom value; role of state; law of tourism

\section{INTRODUCTION}

Bali Culture Tourism is a tourism based on Balinese culture inspired by Hinduism and Tri Hita Karana philosophy. Culture of Tourism Bali has uniqueness that is in one system that is culture, religion of Hindu, culture, art, and custom. The right to travel is the freedom to travel and the use of leisure in the form of a tour is part of human rights [1]. Improving the quality of tourism in Bali can also be seen if tourism desti is able to guarantee the protection of human rights in this case the tourists, and give attention to the quality of environment [2]. The study of tourism in Desa Plaga, operating Bagus Agro Plaga on May 12, 2005, there are still obstacles, especially in the field of promotion, not yet supported other facilities such as art shop, art market. In addition, it has not been supported by objects that have its own Pulling power [3].

Thus tourism is an integral part of national development that is carried out systematically, planned, integrated, sustainable, and responsible while providing protection for religious values, culture that lives in society, environmental sustainability and quality, and national interest [1]. The importance of tourism development, that the development of tourism is needed to encourage equality of business opportunity and benefit and able to face the challenges of changing local, national and global life [1]. Freedom to travel and make use of leisure time in the form of travel, now classified as a human right. In the Indonesian Tourism Law the regulation on sustainable development is contained in the section "weighing the letter $\mathrm{c}$ " which states that tourism is an integral part of national development that is carried out systematically, planned, integrated, sustainable, and responsible while maintaining the protection of religious values , culture that lives in society, environmental sustainability and quality, and national interests [4].

In the formulation of problems relating to the above issues, in this article will address two important issues namely, First, How Cultural Tourism Practices and the Role of Tourism Law to defend the rights of indigenous peoples in Bali ?; Secondly, Is there a correlation of the Value of Local Wisdom in Tourism activities in the Global Era ?. The purpose of the study: (1). To know and recognize how cultural tourism practices and the role of cultural tourism law to defend the rights of indigenous peoples of Bali; (2). To find out if there is a correlation of the Value of Local Wisdom in Tourism activities in the Global Era. Research Methods: The type of research used in sociolegal research uses an interdisciplinary jurisprudence approach in the opinion of Schut in [5] says "Wetenschap is afkijken" (Science is looking in all directions). The point is that legal science does not get caught in a narrow but holistic view of the law has ethical, moral, religious content to create justice, happiness, prosperity, peace. The law moves in three dots: state law, society, and religion, ethics and morals called triangle concept of law [6]. This condition cannot be established if the legal science that leads and forms the law is only positivistic paradigm that struggles with formalistic, procedural, partial, elitist attachment to power and dominated by politics and economy [7]. The point is that the narrow-minded law has ignored the role of human beings both in the process of legislation, implementation, law enforcement, and people in society. Therefore, the science of law in its development cannot be separated from the human element. In this case the legal science emphasis on socio-legal studies is a type of study that represents the way of seeing the law more to the context than the text [8]. In this article, used the method of legal science by referring Soetandyo Widnyosoebroto opinion, see the law of two sides. First, the law as the norm (sollen) and second, the law as nomos (statements about the presence or absence of certain behaviors in a factual collective life.) The first is called the rule, and the second is the order. The definition of law as a rule (norms) and order (nomos, facts) is a duality, not a decotomy. Casually, both are not separate, [8] this is dissected in this article. Furthermore, that law as a norm which, when 
obeyed, it will transform into a steady behavior over a long span, will be understood as the norm.

The theory used is law as a means of social control to quote Roucek, Soerjono Soekanto, calling the mechanism of social control as "everything that is done to carry out planned and unplanned processes to educate, invite or even force the citizens to conform to customs. Habits and values of community life [5]. In addition, Law Theory as social engineering is consciously to achieve order or condition of society as aspired or to make desired changes. Likewise eclectic will use Parsons Theory into law as done by Bredemeir, has been raised the relationship between politics and law. It is proposed that the law regulates further the decisions taken by the political life sector.

\section{METHOD}

This study focuses on reviewing local regulations based on customary law, awig-awig, especially in the tourism activity in traditional village. We collected data using a personal-based experience interview method with some indigenous village leaders in traditional village of Kuta-Bali. We examined local rules using cultural practice and its correlation. We present results through descriptive methods.

\section{RESULT AND DISCUSSION}

\section{A. Cultural Tourism Practices and the Role of Tourism Law to defend the rights of indigenous peoples in Bali.}

Bali before it was declared a tourist destination of Indonesia, when the Dutch Colonial Government in power in the Dutch East Indies also prepared software that supports Bali as a tourist destination. The idea of "Balinesering" is very powerful for the preservation of Balinese culture. This is how the political role of tourism law. In Soeharto's New Order government in his speech on August 16, 1968, Suharto stated that the first stage was to give special attention to the tourism of Bali. Soeharto is using his power to create knowledge that tourism is the only way to succeed Balinese development. In another context the power relations between the Indonesian government of the World Bank. The results of Michel Picard's research that says that in March 1969 the World Bank came to Indonesia to convey suggestions that the Indonesian government to create a master plan for the development of tourism in Bali [6]. This recommendation is accepted by the Government of Indonesia. Through the international tender process, the Indonesian government ordered the preparation of this master plan for the Society Centrale four I'Equipement Touristique Qutre-Mer (SCETO) [6]. Tourism development in Bali, based on SCETO theory, is concentrated on hotels in Nusa Dua, Sanur, and Kuta (Bali Post January 14, page 1). The application of role theory in tourism development planning in Bali especially that proclaimed Cultural Tourism has involved international party for tourism planning that is SCETO. There are not many Balinese organic intellectuals who know the reason President Soeharto accepted the advice of the World Bank. The reason was only widespread in 2007, after the results of research Michel Picard is translated from English to Indonesian. From the research results it can be clearly known, that behind the discourse of tourism industry there are indeed power relations between Soeharto and the World Bank [6]. But the concept of Tourism has emerged in the Dutch colonial period, but has not been referred to as the tourism industry. The term of the new tourism industry was seen during the reign of President Soeharto. But Soeharto is not the originator, because the ideals have been discussed during the reign of Sukarno. Soekarno's interest in tourism can be seen from his decision to build the Bali Bech Hotel in 1962 and Ngurah Rai airfield since 1963 covering research, drilling and dredging of land.

The law as a means of control as used by Satjipto Rahardjo [5] is the law in relation to social change that a process influences people to behave in accordance with the expectations of society. As described above in the history of the birth of tourism in Bali, controlling by law is exercised in various ways and through customary village bodies and individuals and legal entities. In the context of Tourism Law, every person and / or society within and around a tourism destination has priority rights: $a$. become a worker / laborer; $b$. consignment; and / or c. management [1]. In the business and political realities that the local community mostly acts as the security (security) of the hotel because of the human resources of Bali (Interview with Drs I Wayan Mendra., M.Si, December 27, 2017) [9]. It is proven some Krama indigenous villages of Tuban who can only enjoy Bali Culture cake tourism as a security at Hotel Soverign. In the local law of the indigenous village of Tuban can regulate it in the awig-awig and / or perarem products of palemahan and pawongan in the indigenous village of Tuban. In the public policy of Indonesian tourism with the hope of tourism law, the state can defend the rights of indigenous people of Bali, is it true? A paradox between cultural tourism and the WTO (World Trade Organization) of a world trade organization that is an international body established on 1 January 1995 and specifically regulates a free and open multilateral inter-state trade system [10]. Then was born the Law of the Republic of Indonesia Number 10 Year 2009 on Tourism, Article 5, Tourism with the principle [1]:

- Upholding religious norms and cultural values as the embodiment of the concept of life in the balance of the relationship between man and God Almighty, the relationship between humans and human beings, and the relationship between humans and the environment.

- Upholding human rights, cultural diversity, and local wisdom.

Tourism law politics associated with Desa Pakraman states that the management of tourist attraction can be done by Provincial Government, Pakraman Village, traditional institution, individual and business entity [11]. Furthermore, it is mentioned that Pakraman villages and traditional institutions have the right to develop rural tourism according to local potential; and managers of tourist attraction are entitled to provide special guides (Article 26 paragraph (2.3)). In this context, customary institutions (adat villages / pakraman villages), traditional institutions have the right to develop rural tourism according to local potential; in this case also that the management of Attraction is entitled to provide special guides [11]. In the development of Bali tourism, the provincial government may provide financial support for the development 
of tourism managed by indigenous villages or pakraman villages [11]. When looking back, by passing through several phases of governmental rule, the design of tourism development prioritizes synergy with cultural entities. In the framework of cultural diversity relationships can be used as the basic capital of tourism development. If the government of Bali Province wishing to prepare tourism Culture based on indigenous village, hence adat village should be empowered its human resource so that really tourism based on culture and by reviving local tradition.

Balinese culture is built through a very long civilization process, from prehistoric times to modern civilization, and the global era. In the pressures and effects of the fast and complex system of modern and global civilization, Balinese culture exhibits dynamic, selective, flexible, and effective nature. Pariwiata activity is a multi-aspect activity, national and international, has function as agent of economic development and agent of cultural development covering multidimensional aspects, therefore tourism law policy must be directed to tourism law must be able to consider the characteristic, function, and all aspects of tourism business activities; [12]. The policy of Bali Provincial Government in revitalizing the culture, by always considering Hinduism as the basis and the buffer of Bali tourism is a supporting factor that resulted in Bali remains a tourist destination with tourism objects and attractions that are characteristic of Balinese culture and religion Hindu [13]. Law as one element of culture in a regulatory system, that can be understood anatomy with jabaran that, the law is one of several institutions in society that helped create order. In this context tourism and culture must be able to provide welfare, happiness for humans in Bali, especially Hindus as a supporter of culture. Parson says that the human being is controlled by certain information flows that he receives from the highest source that Parson calls ultimate reality. Then formulated as "the truth of teak" [14,15].

\section{B. Correlation of the Value of Local Wisdom in Tourism Activities in the Global Era (Reflection and Reconstruction of Tourism Law).}

The reflection of the authors' thoughts on Bali about the value of local wisdom will have an effect on Global Tourism activities if lawmakers are able to design "legal products" what will happen due to cultural, scientific, economic, security, criminal phenomenon, tourism activities for the benefit of indigenous peoples customs in Bali. When society changes drastically and dynamically, the law especially legislation tends to be slow and static in pursuit of such changes. No wonder there is a law that says: het recht hink achter de feiten aan (the law is always striving to pursue events that should be arranged) [16]. From the "optic" sociology the function of modern law today is not just waiting for the occurrence of conflict or conflict of interest, then the law works to resolve dispute (dispute-setting function), but the law is more required to function actively in the life of modern society. With regard to Tourism in Bali, the law should anticipate what sociology should not be called: social lag, economic lag, or cultural lag, i.e. the backwardness experienced by certain groups in society. In considering (b) Bali Province Regional Regulation No. 2 of 2012 on Cultural Tourism [11], states that the development of
Bali tourism aims to encourage equal distribution of business opportunities and gain the maximum benefit for the welfare of society so that the realization of tourism ideals for Bali and not Bali to tourism. These noble words are not sufficiently "written", "pronounced" an ideal, yet sociologically must be "earthed" in the reality of tourism culture in Bali at the traditional village level in Bali in socio-religious life, societal economy. The essence of Balinese culture is imbued by Hinduism with the concept of Tri Hita Karana as the basis in the life of Balinese people to achieve the purpose of life "Moksratham Jagadhita Ca Iti Daharma" that is the aim of darma is the world's welfare and the Hereafter (niskala). In the concept of Tri Hita Karana that teaches the pattern of the balance of human relationships, either with God (Parhyangan), with each other (Pawongan) and with the environment (palemahan). Thus the management of Cultural Tourism "is based on Hinduism and Balinese culture rooted in religion, and Balinese traditions.

In the context of the value of local wisdom in Bali in particular this article explains the role of indigenous village of Kuta that is associated with silence day and tourism activities can be explained that in this context the role of Pacalang in Desa Adat Kuta for the safeguarding of the Kuta beach and can also double to provide security to indigenous peoples conducting religious / ritual procession and protection to foreign tourists and Nusantara tourists. In this case the role of awig-awig Desa Adat Kuta to produce order and security of traditional village (local law indigenous village of Kuta, 1984: 55). In the dynamics of tourism the role of pacalang is normatively established in 1984 in Desa Adat Kuta and has been protected. He served to kesukertan jagat ring penyepian, which ranging from melis/mekiis or melasti to securing brata penyepian. Pecalang in Kuta Adat Village is very sacred and only served on Nyepi (religious) day. Perhaps in other pakraman villages it has grown, which is to assist the village offices in controlling the population, but in Desa Adat Kuta specifically for religious purposes (Interview with I Made Minder Former Kelian Pecalang Desa Adat Kuta on March 4, 2017) [17]. Then Pacalang adopted in Provincial Village Law No. 3 of 2001 [18], then held a change based on Perda Desa Pakraman No. 3 of 2003, Article 17 [19].

The role of Pacalang in tourism needs to be given adequate guidance and tasks will strengthen the concept of cultural tourism. Similarly, the provincial government of Bali can explicitly make public policy by making products "of the Bali Provincial Regulation on the role and function of the Pacalang in tourism activities. In this context, if the "state" is not present reformulating the Tourism culture of Bali through legal products and the role of oversight will bring about cultural discontinuity. In order for the society to be orderly in the tourism law traffic, adat villages can play a role to regulate their communities in traditional villages through legal products (customary law, awig-awig adat village / pakraman) made by adat villages and authorized by the government namely the Regent / gain juridical power, that sovereignty in the juridical sense exists in the state $[15,20]$. In the context of this tourism, the value of local wisdom in Bali has been excavated by Bali Provincial Government, especially art to be presented in Bali Arts Festival (PKB), various dances revitalized to support the 
tourism of Balinese culture. In line with the authors' opinion that, Ardika [21] predicted that in the globalization era, issues such as culture, religion, ethnicity, gender and life style will be more important than the industrial conflicts. In this connection Ardika exemplifies archaeological relics, as the past cultural heritage remains a source of inspiration.

- In this context, there needs to be a format and issue of legal change and community change. According to Achmad Ali, [22] to answer that the "role of the state" in tourism in Bali requires two important points of law and community change, as follows:

- The extent to which changes in society must be subject to adjustments by law. In other words, how the law adapts to the change of society. This shows the nature of the law.

- The extent to which the law plays a role in moving society toward a planned change. Here the law plays an active role, and this is often referred to as the legal function of "a tool of social engineering" as a tool of community engineering.

In the context of this public policy, the role of executive and legislative "state" in producing regulations and legislation in tourism primarily provides protection for religious values, living culture in society, sustainability and environmental quality, and national interests. According to Thomas Aqunas in the theory of natural law, the law defined as another act is the command of reason for the common good and is promoted by those who have the authority to foster society. It is the source of positive law in terms of the concept of justice, the correlation of virtue with moral and social justice, and the legal obligation with moral obligations. The influence of tourism neo-liberalism in Bali needs to be guarded and watched by the "state" and the government, and society both as the subject of tourism and "object" in the activity of art in the tourism context. The influence of materialistic phenomena, commercialism and individual mentality is the result of social pathology in Balinese society, especially religious objects (pratima di tempura), theft, other social diseases, such as prostitution.

\section{CONCLUSION}

The state has a role to defend the rights of indigenous villages in Bali because it has a uniqueness that is not owned by other countries, so the concept of cultural tourism can be sustainable according to the expectations of indigenous Balinese Hindus. Today indigenous peoples and adat villages in Bali are faced with the concept of tourism neolibelism / capitalism that competes with capitalism funders. The inclusion of tourism capitalism in Bali globally needs serious handling to give local people a driving force for Balinese cultural tourism as a concept that is sustainably championed in global tourism. To that end, the role of the state becomes very important in regulating, protecting indigenous peoples and traditional Balinese villages based on Hinduism and the philosophy of Tri Hita Karana. Bali's tourism policy with the concept of cultural tourism provides a role for the government to produce "tourism laws" that favor the rights of the Balinese people both in concept and in implementation for the benefit of indigenous villages in sustainable tourism management for the welfare of the Balinese people in particular and the community Indonesia generally. The role of Bali's legislative and executive should contribute to the support of Balinese culture in a sustainable manner. Tourism activity in Bali, law must be able to anticipate not to happen social lag, economic lag, or cultural lag, that is backwardness experienced by certain groups in indigenous society of Bali which social religious, which only as "spectacle of tourism", country able to give the protection of sustainable tourism business law that is aligned with Bali's indigenous peoples.

\section{ACKNOWLEDGEMENT}

The author would like to thank all the parties who have helped and contributed in the writing of this article, both those who contribute in the form of funding and critical ideas. Hopefully this paper can be useful theoretically and practically for the addition and development of knowledge, especially in the field of legal science.

\section{REFERENCES}

[1] Undang-Undang Republik Indonesia Nomor: 10 Tahun 2009 tentang Kepariwisataan, Lembaran Negara Republik Indonesia Tahun 2009 Nomor: 11.

[2] I. Prabhata, I. G. A. Ngurah, Meningkatkan Pariwisata Bali Melalui Kepastian Penegakan Hukum atas pelanggaran Kawasan tanpa rokok dalam Peraturan Daerah Provinsi Bali Nomor 10 tahun 2011, dalam Udayana Law Journal, vol 4 Nomor 1. 2015.

[3] S. S. I Ketut, Perkembangan Pariwisata di Desa Plaga, dalam "Jurnal Ilmiah Fakultas Hukum Universitas Udayana KERTHA PATRIKA", Denpasar. 2011.

[4] S. Dharmawan, N. Nyoman, "The rights to Tourism" dalam Perspektif Hak asasi Manusia di Indonesia" dalam Jurnal Ilmiah Fakultas Hukum Universitas Udayana Kertha Patrika, Denpasar, Fakultas Hukum Unud. 2011.

[5] S. Rahardjo, Hukum dan Perubahan Sosial Suatu Tinjauan Teoritis Serta Pengalaman-Pengalaman di Indonesia, Genta Publishing, Yogyakarta. 2009.

[6] Menski, W. F., Comparative law in a global context: the legal systems of Asia and Africa. Cambridge University Press. 2006.

[7] E. Warasih, Ilmu Hukum Kontemplatif (Surgawi \& Manusiawi), "Dalam Penelitian Hukum Interdisipliner sebuah Pengantar menuju SosioLegal", Thafamedia, Yogyakarta. 2016.

[8] Shidarta, Sosio-Legal dalam Perkembangan Metode Penelitian Hukum," Dalam Penelitian Hukum Interdisipliner sebuah Pengantar menuju Sosio-Legal", Thafamedia, Yogyakarta. 2016.

[9] Drs I Wayan Mendra,M.Si, alamat Br. Pesalakan Tuban-Kuta, Jabatan: Bendesa Adat Tuban, Umur: 63 tahun.

[10] P. C. K. L. Bello, Idelogi Hukum Refleksi Filsafat atas Ideologi di Balik Hukum, Insan Merdeka, Bogor. 2013.

[11] Peraturan Daerah Provinsi Bali Nomor 2 Tahun 2012 tentang Kepariwisataan Budaya Bali, Lembaran Daerah Provinsi Bali Tahun 2012 Nomor 2.

[12] W. Putra, I. Bagus, Hukum Bisnis Pariwisata,Refika Aditama, Bandung. 2015.

[13] Arka, I. W., Eksistensi Lembaga Perkreditan Desa dalam Pembangunan Desa Pekraman sebagai Desa Wisata di Bali. 2016.

[14] S. Rahardjo, Ilmu Hukum, Bandung, Citra Aditya Bakti, 2012. 
[15] Astara, I W. W., Dinamika Politik Kebudayaan, Hukum, dan Pariwisata Bali "dalam Ragam Wacana Bahasa, Sastra dan Budaya", Bunga Rampai, Pustaka Pelajat, Yogyakarta. 2015.

[16] A. Ali, W. Heryani, Menjelajahi Kajian Emperis Terhadap Hukum, Kencana, Jakarta. 2012.

[17] I M. Minder, alamat, Desa adat Kuta, Jabatan: Mantan Kelian Pecalang Desa Adat Kuta, umur: 65 tahun.

[18] Undang-Undang Republik Indonesia Nomor 3 Tahun 2001 tentang Desa Pakraman.
[19] Undang-Undang Republik Indonesia Nomor 3 Tahun 2003, tentang Perubahan atas peraturan Daerah Propinsi Bali Nomor 3 tahun 2001 tentang Desa Pakraman.

[20] T. Huijbers, Filsafat Hukum, Kanisius, Yogyakarta. 1999.

[21] A. I Wayan, "Warisan Budaya dan Globalisasi" (dalam makalah Matrikulasi Program Magister S-2 Kajian Budaya Universitas Udayana 10 Juli-14 Agustus 1999 di Denpasar). 1999.

[22] A. Achmad, Menguak Tabir Hukum (suatu Kajian Filosofis dan sosiologis), PT Gunung Agung, Jakarta. 2002. 